\title{
Fibrin-fibrinogen degradation products in cerebrospinal fluid
}

\author{
M. J. BRUETON, G. R. BREEZE, AND J. STUART \\ From the Department of Haematology and Institute of Child Health, Children's Hospital, Birmingham B16 $8 E T$
}

SYNOPSIS An increase in low molecular weight fibrin-fibrinogen degradation products (FDP) was demonstrated in cerebrospinal fluid (CSF) from 17 of 18 patients with bacterial or viral meningitis compared with 29 patients without meningitis. The CSF also showed an increase in coagulation proteins of molecular weight less than 90000 (factors VII, IX, and plasminogen) but did not contain fibrinogen (MW 340000 ) or plasminogen activator. It is concluded that low molecular weight FDP in the CSF in infective meningitis result from leakage through a damaged blood-CSF barrier rather than from local digestion of fibrin deposited on the meninges.

Fibrin-fibrinogen degradation products (FDP) are not found in normal cerebrospinal fluid (CSF) but have been demonstrated following subarachnoid haemorrhage (Tovi, 1972), meningococcal meningitis (Brueton et al, 1974), and in patients with raised CSF protein (Hunter et al, 1974). The source of origin of the FDP is not clear although this is an important point in view of the potential diagnostic value of raised FDP and also in relation to the treatment of subarachnoid haemorrhage by fibrinolytic blockade (Mullan and Dawley, 1968; Gibbs and Corkill, 1971 ; Tovi, 1972).

Normal CSF does not contain plasminogen activator (Tovi, 1972) although the meninges and choroid plexus are rich in this fibrinolytic activator. The release of an increased amount of activator from these tissues could therefore result in the local digestion of fibrin-fibrinogen to give rise to FDP in the CSF. Alternatively, FDP could leak into the CSF via a damaged blood-CSF barrier. The latter would be analogous to the appearance of low molecular weight FDP in the urine when glomerular basement membrane damage results in highly selective proteinuria (Hall et al, 1975).

A study has therefore been made of coagulationfibrinolytic proteins of differing molecular weight in the CSF and blood from 47 patients undergoing diagnostic lumbar puncture in order to determine the source of origin of FDP in the CSF in meningitis.

\section{Patients and Methods}

Fifty-eight specimens of CSF were obtained from 47 patients undergoing diagnostic lumbar puncture.

Received for publication 30 September 1975
The 47 patients (42 were children) included 13 patients with bacterial and five with viral meningitis (meningitis group). The remaining 29 patients (nonmenigitis group) comprised 10 with acute lymphoblastic leukaemia (three with meningeal involvement), five with febrile convulsions, and eight with infections such as pneumonia which did not involve the CNS but were associated with meningism; the remaining six patients had a variety of conditions affecting their level of consciousness but without evidence of CNS infection. Patients with bacterial meningitis were initially treated for two weeks with either parenteral chloramphenicol, penicillin, and sulphadimidine, or intravenous ampicillin.

Lumbar CSF $(1.0 \mathrm{ml})$ was taken directly into a plastic tube containing $0.1 \mathrm{ml}$ of $3.8 \%$ sodium citrate for estimation of plasminogen, fibrinogen, and factors VII and IX, and $0.5 \mathrm{ml}$ was taken into 250 units of aprotinin in a dry container for estimation of FDP. The specimens were transported immediately to the laboratory and centrifuged at $0-4^{\circ} \mathrm{C}$. Thrombin $(0.1 \mathrm{ml}$ of a $50 \mathrm{unit} / \mathrm{ml}$ concentration) was added to the supernatant of the specimen containing aprotinin and, after incubation at $37^{\circ} \mathrm{C}$ for 15 minutes, the specimen was assayed for FDP using ThromboWellcotest (Wellcome Reagents Ltd) and Diagen (Diagnostic Reagents Ltd) latex slide tests and also the tanned red cell haemagglutination inhibition immunoassay (TRCHII) of Merskey et al (1966).

Venous blood $(1.0 \mathrm{ml})$ was taken into a ThromboWellcotest kit sample tube (containing thrombin and aprotinin) for FDP estimation by the three methods.

Plasminogen in CSF was estimated by the method of De Vreker (1965), factor IX by one-stage assay (Hardisty and Ingram, 1965), and factor VII by a one-stage method (Stefanini, 1950) substituting fac- 


\begin{tabular}{lrll}
\hline Test & \multicolumn{2}{l}{ Result } & Units \\
\hline Thrombo-Wellcotest & $<8(34)$ & $\mathrm{mg} / \mathrm{l}$ \\
Diagen & $<4(34)$ & $\mathrm{mg} / \mathrm{l}$ \\
TRCHII & $<5(34)$ & $\mathrm{mg} / 1$ \\
Plasminogen & $<10(24)$ & $\mathrm{units}$ \\
Fibrinogen & 0 & $(32)$ & $\mathrm{g} / 1$ \\
Factor VII & 0 & $(7)$ & $\%$ \\
Factor IX & 0 & $(7)$ & $\%$ \\
Fibrin plate lysis & $<60(8)$ & $\mathrm{mm}$ \\
Protein & $<0.5(31)$ & $\mathrm{g} / \mathrm{l}$ \\
\hline
\end{tabular}

Table I Range of values obtained from 34 CSF specimens from 29 patients without meningitis

The number of CSF samples studied for each test is stated in parentheses.

tor VII-deficient plasma and omitting adsorption with aluminium hydroxide. Plasminogen activator was measured using human fibrin plates (Astrup and Müllertz, 1952; Cash and Allan, 1967). Red and white cell counts on CSF were performed using an improved Neubauer counting chamber, and identification of leukaemic blast cells was confirmed by cytocentrifugation. CSF protein was estimated according to King and Haslewood (1936). Citrated samples of CSF for fibrinogen estimation were tested undiluted and diluted $1 / 1-1 / 8$ in glycylglycine buffer and then reacted with Diagen test reagent which incorporates an antiserum against whole fibrinogen.

Statistical significance was determined using Student's $t$ test and correlation coefficient. Molecular weight values for coagulation factors were obtained from Hardisty (1974).

\section{Results}

NON-MENINGITIS GROUP

The range of CSF values obtained for this group is given in table I. Of the 29 patients studied, only two showed FDP values in the CSF (by the Thrombo은 Wellcotest method) and in low concentration (< $\mathrm{mg} / \mathrm{l})$; the remaining 27 patients had no detectable FDP by all three methods studied. None of $24 \mathrm{CS}$ samples contained detectable plasminogen; the lower limit of sensitivity of the test was 10 units? None of the CSF samples tested contained demon strable fibrinogen, factor VII or factor IX, or showe屯ึ plasminogen activator activity.

MENINGITIS GROUP

The results obtained for the 18 patients are given is table II. The FDP values are stated for the Thromboe Wellcotest method only since this was the most sensi tive of the three methods studied; it gave a raised value ( $16 \mathrm{mg} / \mathrm{l}$ or above) in 17 of the 18 patients, and in 10 patients it was the only test of the three to give $\vec{a}$ raised FDP value. The FDP values obtained by the Thrombo-Wellcotest were consistently higher than the values obtained by the two other methodso The increased reactivity of the low molecular weight FDP fragments FgD and FgE (MW 50-83000 in the Thrombo-Wellcotest compared with tho Diagen latex test has previously been reported (Donati et al, 1973).

Plasminogen values in the CSF were raised in 11 of 13 patients studied, factor IX was detected in five og seven CSF samples, and CSF protein was raised in 14 of the 18 patients. None of the samples showed any increase in plasminogen activator activity by the fibrin plate method or contained detectable fibrino gen.

CORRELATION WITH CSF ERYTHROCYTE COUNT

Nine of the 29 patients without meningitis showed

\begin{tabular}{|c|c|c|c|c|c|c|c|c|}
\hline \multicolumn{2}{|l|}{$F D P(m g / l)$} & \multirow{2}{*}{$\begin{array}{l}\text { Plasminogen } \\
\text { (units) }\end{array}$} & \multirow{2}{*}{$\begin{array}{l}\text { Factor IX } \\
(\%)\end{array}$} & \multirow{2}{*}{$\begin{array}{l}\text { Factor VII } \\
(\%)\end{array}$} & \multirow{2}{*}{$\begin{array}{l}\text { Protein } \\
(\mathrm{g} / l)\end{array}$} & \multirow{2}{*}{$\begin{array}{l}\text { Erythrocytes } \\
\left(\times 10^{8} / I\right)\end{array}$} & \multicolumn{2}{|c|}{$\begin{array}{c}\text { Leucocytes음 } \\
\left(\times 10^{\circ} / l\right)\end{array}$} \\
\hline$C S F$ & Serum & & & & & & & \\
\hline $16-32$ & - & 70 & - & - & $1 \cdot 0$ & 6 & 30 & \\
\hline $16-32$ & - & 180 & - & - & $1 \cdot 0$ & 4000 & 0 & \\
\hline $32-64$ & - & 100 & - & - & $3 \cdot 0$ & 2800 & 3400 & \\
\hline $128-256$ & $16-32$ & 70 & - & 一 & 0.6 & 500 & 2500 & N \\
\hline $32-64$ & $256-512$ & - & - & - & $3 \cdot 0$ & 770 & 2100 & N \\
\hline $128-256$ & $32-64$ & 120 & 14 & 5 & $2 \cdot 5$ & 1000 & 12000 & $\omega$ \\
\hline $32-64$ & $<8$ & - & - & - & 03 & 0 & 282 & $\sigma$ \\
\hline $16-32$ & - & 0 & 0 & 0 & $3 \cdot 0$ & 120 & 8000 & (ת) \\
\hline $32-64$ & $16-32$ & 24 & 6 & 0 & 0.5 & 200 & 1400 & 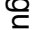 \\
\hline $64-128$ & $32-64$ & 80 & 42 & 30 & $1 \cdot 5$ & 95 & 24500 & $\frac{1}{(D)}$ \\
\hline $64-128$ & $8-16$ & 100 & 4 & 0 & $2 \cdot 5$ & 0 & 13000 & $\stackrel{+}{\leftrightarrows}$ \\
\hline $16-32$ & $<8$ & - & 一 & - & $0 \cdot 2$ & 6 & 8 & \\
\hline $128-256$ & $8-16$ & 10 & - & - & 0.4 & 1200 & 25 & $\underset{T}{T}$ \\
\hline $128-256$ & $16-32$ & 320 & 20 & 15 & $3 \cdot 7$ & 210 & 5600 & Oे \\
\hline $16-32$ & $<8$ & - & - & - & 0.9 & 0 & 700 & $\vec{D}$ \\
\hline $16-32$ & $<8$ & - & - & - & 0.8 & 160000 & 114 & Q \\
\hline $64-128$ & $<8$ & 80 & 0 & 0 & $1 \cdot 3$ & 1000 & 20 & (D) \\
\hline $4-8$ & $<8$ & 20 & - & - & 0.3 & 120 & 160 & \\
\hline
\end{tabular}

Table II CSF results for the 18 patients in the meningitis group: serum FDP levels given for comparison 
raised CSF erythrocyte count (range 20-2400 $\times$ $10^{6} / 1$ ) but there were no detectable FDP (ThromboWellcotest) in eight of the nine; the ninth patient showed FDP of only 4-8 mg/l. Of 12 patients in the meningitis group with $120-160000 \times 10^{6}$ erythrocytes/l CSF, there was an increase in FDP in 11 ; conversely, five patients with raised FDP levels in the CSF showed no erythrocytes or only $6 \times 10^{6} / 1$. In patients with both a raised FDP level and erythrocyte count in the CSF there was no significant correlation between the individual values $(r=0.09, \mathrm{P}>0.5)$. Similarly, there was no significant correlation between CSF erythrocyte count and factor IX level $(r=0.014, P>0.5)$.

\section{RELATIONSHIP BETWEEN FDP IN THE SERUM} AND CSF

Of the 17 patients with raised FDP (ThromboWellcotest) in the CSF, the serum FDP level was measured in 14 and found to be raised (range 16-512 $\mathrm{mg} / \mathrm{l}$ ) in six (table II). The patient with the very high serum FDP level $(256-512 \mathrm{mg} / \mathrm{l})$ also suffered from septicaemia.

\section{SEQUENTIAL CSF STUDY}

Serial samples of CSF were obtained from three patients in the meningitis group with persistent or progressive neurological signs. In a child who developed hydrocephalus, FDP were still present in the CSF after five weeks, and in an infant with severe diffuse cerebral damage they were still present at six weeks. The latter patient also developed bilateral subdural effusions which contained a high concentration of FDP $(1024 \mathrm{mg} / \mathrm{l})$. In a third patient, who developed a hemiplegia, the FDP level was still rising after two weeks. In all three patients, serum FDP were very low or undetectable.

\section{Discussion}

This study has shown that the concentration of low molecular weight FDP, and also coagulation proteins of molecular weight less than 90000 , was either very low or undetectable in CSF from 29 patients with no demonstrable inflammatory disease of the meninges. In contrast, 17 of 18 patients with bacterial or viral meningitis showed an increase in low molecular weight FDP in the CSF when measured by a latex test incorporating antibody against $\mathrm{FgD}$ and FgE (MW 50-83 000). The FDP were usually accompanied by plasminogen (MW 89000 ), protein, and factors VII (MW 35-63000) and/or IX (MW 50 000) but not by fibrinogen (MW 340000 ) or plasminogen activator.

The individual levels of FDP and factor IX did not correlate with the number of erythrocytes in the CSF so that the selective increase in low molecular weight proteins is unlikely to have resulted from contamination with blood at the time of lumbar puncture. It seems more likely that the leakage resulted from inflammatory damage to the blood-CSF barrier. Since the half-life of FDP is approximately 5-15 hours (Hardisty, 1974) and since the CSF is probably renewed every 6-8 hours (Milhorat, 1972), the persistence of small molecular size FDP and other proteins in the CSF for several weeks in three patients with a local complication of meningitis is suggestive of continued leakage of this type. Fibrin deposition on the meninges and its subsequent lysis could also give rise to FDP in the CSF; in the present study, however, there was no demonstrable increase in CSF plasminogen activator as might be expected if this were a major mechanism.

Raised FDP levels in the CSF were sometimes found in the absence of raised serum FDP. The cerebral vessels in meningitis may show areas of arteritis with occlusion (Thomas and Hopkins, 1972) and also vasodilatation (Leeds and Goldberg, 1971) so that local fibrin deposition and breakdown could result in a high local concentration of FDP with direct leakage into CSF. The accompanying rise in FDP in the serum of some patients may be secondary to this local production in the cerebral vessels or arise systemically as a consequence of transient viraemia, bacteraemia or endotoxaemia.

FDP may also appear in the CSF following subarachnoid haemorrhage (Tovi, 1972) and this has been explained on the basis of secondary fibrinolytic digestion of the fibrin clot. This explanation is the rationale for the use of fibrinolytic blockers such as epsilon aminocaproic acid to prevent re-bleeding (Mullan and Dawley, 1968; Gibbs and Corkill, 1971; Tovi, 1972). Patients with subarachnoid haemorrhage do not, however, show increased plasminogen activator activity in the CSF (Tovi et al, 1972), as would be expected with increased fibrinolysis, and the present study of meningitis has indicated an alternative mechanism for the occurrence of FDP in CSF. Further studies of this type are therefore indicated in subarachnoid haemorrhage, and also in patients with raised CSF protein of non-inflammatory origin (Hunter et al, 1974) and in infants with birth asphyxia who show excess protein in ventricular CSF and are prone to intraventricular haemorrhage (Cole et al, 1974).

We are indebted to the Central Birmingham Health District Trust Funds for financial support, to the physicians of the Children's and East Birmingham Hospitals for allowing access to their patients, and to the house staff for collecting additional volumes of CSF and blood at diagnostic puncture. Reprint requests to MJB, Institute of Child Health. 


\section{References}

Astrup, T., and Müllertz, S. (1952). The fibrin plate method for estimating fibrinolytic activity. Arch. Biochem., 40, 346351 .

Brueton, M. J., Tugwell, P., Whittle, H. C., and Greenwood, B. M. (1974). Fibrin degradation products in the serum and cerebrospinal fluid of patients with group A meningococcal meningitis. J. clin. Path., 27, 402-404.

Cash, J. D., and Allan, A. G. E. (1967). Effect of mental stress on the fibrinolytic reactivity to exercise. Brit. med.J., 2, 545-548.

Cole, V. A., Durbin, G. M., Olaffson, A., Reynolds, E. O. R., Rivers, R. P. A., and Smith, J. F. (1974). Pathogenesis of intraventricular haemorrhage in newborn infants. Arch. Dis. Childh., 49, 722-728.

De Vreker, R. A. (1965). A technique for routine evaluation of plasminogen in humans during streptokinase therapy. Acta. haemat. (Scand.), 34, 305-320.

Donati, M. B., Semeraro, N., and Vermylen, J. (1973). Detection of fibrinogen antigens with two latex techniques applied to urine concentrates. J. clin. Patk., 26, 760-763.

Gibbs, J. R., and Corkill, A. G. L. (1971). Use of an antifibrinolytic agent (tranexamic acid) in the management of ruptured intracranial aneurysms. Postgrad. med. J., 47, 199-200.

Hall, C. L., Pejhan, N., Terry, J. M., and Blainey, J. D. (1975). Urinary fibrin-fibrinogen degradation products in nephrotic syndrome. Brit. med. J., 1, 419-422.

Hardistry, R. M. (1974). In Blood and its Disorders, edited by R. M. Hardisty and D. J. Weatherall, p. 223. Blackwell, Oxford.

Hardisty, R. M., and Ingram, G. I. C. (1965). Bleeding Dis-

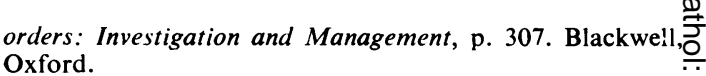

Hunter, R., Thomson, T., Reynolds, C. M., and Pitcher, P. M. (1974). Fibrin/fibrinogen degradation products in cere- $\stackrel{\oplus}{+}$ brospinal fluid of patients admitted to a psychiatric unit. J. Neurol. Neurosurg. Psychiat., 37, 249-251.

King, E. J., and Haslewood, G. A. D. (1936). Permanent standards for the turbidometric estimation of protein. $\overrightarrow{\mathbb{D}}$ Lancet, 2, 1153

Leeds, N. E., and Goldberg, H. I. (1971). Angiographicon manifestations in cerebral inflammatory disease. Radiology, 98, 595-604.

Merskey, C., Kleiner, G. J., and Johnson, A. J. (1966).Quantitative estimation of split products of fibrinogen in $\vec{\omega}$ human sera, relation to diagnosis and treatment. Blood, 28 . $1-18$.

Milhorat, T. H. (1972). Hydrocephalus and the Cerebrospina? Fluid, p. 5. Williams and Wilkins, Baltimore.

Mullan, S., and Dawley, J. (1968). Antifibrinolytic therapyfor intracranial aneurysms. J. Neurosurg., 28, 21-23.

Stefanini, M. (1950). New one-stage procedures for the $\rightarrow$ quantitative determination of prothrombin and labileo factor. Amer. J. clin. Path., 20, 233-240.

Thomas, V. H., and Hopkins, I. J. (1972). Arteriographicdemonstration of vascular lesions in the study of neurolo gic deficit in advanced haemophilus influenzae meningitis Develop. Med. Child Neurol., 14, 783-787.

Tovi, D. (1972). Studies on fibrinolysis in the central nervous system with special reference to intracranial haemorrhages and to the effect of antifibrinolytic drugs. Umeä Universit Medical Dissertations, no. 8, 1-50.

Tovi, D., Nilsson, I. M., and Thulin, C.-A. (1972). Fibrinolysis and subarachnoid haemorrhage, inhibitory effect tranexamic acid. Acta neurol. scand., 48, 393-402. 